\title{
Comparing the expectations, experiences and legacies of volunteers at the FIS Nordic World Ski Championships in Oslo 2011 and Val di Fiemme 2013
}

\author{
Martin Schnitzer ${ }^{1, *}$, Elsa Kristiansen ${ }^{2,3}$ \& Dag Vidar Hanstad ${ }^{3}$ \\ 1 Department of Sport Science, University of Innsbruck, Innsbruck, Austria \\ 2 School of Business, History and Social Sciences, University College of Southeast Norway, Vestfold, Norway \\ 3 Department of Cultural and Social Studies, Norwegian School of Sport Sciences, Oslo, Norway \\ * Corresponding author: Department of Sport Science, University of Innsbruck, Fürstenweg 185, 6020 Innsbruck, Austria, Tel: +43 512 50745865 , \\ Email: martin.schnitzer@uibk.ac.at
}

\section{ORIGINAL ARTICLE}

Article History:

Submitted $3^{\text {rd }}$ March 2017

Accepted 14 $4^{\text {th }}$ September 2017

Published 23 $3^{\text {rd }}$ January 2018

Handling Editor:

Otmar Weiß,

University of Vienna, Austria

Editor-in-Chief:

Martin Kopp

University of Innsbruck, Austria

Reviewers:

Reviewer 1: Siegfried Nagel, University of Bern, Switzerland Reviewer 2: Norbert Schütte, Johannes Gutenberg University Mainz, Germany

\section{ABSTRACT}

Volunteers play an important role in delivering events, especially events over a longer period of time. For example, the FIS Nordic World Ski Championships (Nordic WSC) take place every two years in a member country of the International Ski Federation (FIS). These events usually last 12 days and combine competitions in cross-country skiing, ski jumping and Nordic combined. Furthermore, volunteers also represent one of the biggest groups of stakeholders taking part in the event. The purpose of this article is to shed light on the expectations, experiences and legacies as perceived by volunteers at two events of the same type (Nordic WSC), but staged in two different places and two different cultural settings.

Therefore, 29 volunteers were interviewed; some of them at the FIS Nordic WSC in Oslo and the other half at the FIS Nordic WSC in Val di Fiemme.

The interviews underline that people volunteer for many different reasons, whereat Norwegian volunteers displayed a more individualistic orientation, Italian volunteers showed a greater commitment to their local community. In addition, Italian volunteers felt appreciated by the FIS for the good organization of the events. Other differences were found in the field of community acknowledgement. Norwegian volunteers added that the Norwegian economy would not appreciate this type of experience, whereas in Italy students had to volunteer, which was also appreciated by the community.

The results show that the retention rate may be higher in Val di Fiemme due to the Nordic WSC being a project-based undertaking. Hence, local community loyalty or simply hobbies could show an increase in retention. For future events further research should be undertaken in this field of research.

Keywords:

sport events - volunteerism - expectations - experiences - legacies

Citation:

Schnitzer, M., Kristiansen, E. \& Hanstad D. V. (2018). Comparing the expectations, experiences and legacies of volunteers at the FIS Nordic World Ski Championships in Oslo 2011 and Val di Fiemme 2013. Current Issues in Sport Science, 3:002. doi: 10.15203/CISS_2018.002 


\section{Introduction}

"Volunteers are the lifeblood of the Olympic Games and part of the DNA of thousands of people in this country," said Sebastian Coe, Chair of the London 2012 Organizing Committee (IOC, 2012) and underlined the obvious fact that major sport events wouldn't be feasible without the help of many volunteers. The FIS Nordic World Ski Championships (Nordic WSC) can be considered a major sport event (Parent \& Smith-Swan, 2012), which takes place every two years in a member country of the International Ski Federation (FIS). Due to the frequency of this event, Finland already hosted the Nordic WSC eight times, while Italy (1927, 1941, 1991, 2003 and 2013) and Norway (1930, 1966, 1982, 1997 and 2011) hosted the Championships five times each. Nevertheless, there are some cultural differences between Norway and Italy when it comes to Nordic skiing. In Norway cross-country skiing is considered the national sport; if you are the best in the country, you are usually also among the top skiers in the world. Ski jumping is also important and has a long tradition in Norway. While cross-country skiing has a long tradition and successful athletes in Italy, too, ski jumping is hardly practiced at all.

In order to cope with the financial burden of hosting a major sport event, the free work of a large and varied group of volunteers is a necessity. The complex logistics makes the volunteers important for the successful delivery of these events and the volunteers become a key stakeholder. Furthermore, event volunteerism is a typical ad hoc (and short-term) form of participation, where the event is the central point. Event volunteers are usually involved with annual events, often over many years (Doherty, 2009). This may be problematic when hosting World Championships with a more extensive structure. Over a period of 12 days competitions in cross-country skiing, ski jumping and Nordic combined take place, usually at a variety of different venues. As a result, new groups of sport volunteers may appear, as a large international event attracts volunteers with a particular interest in the sport or volunteers who are attracted by major events (Overbye \& Wagner, 2014). The increase in volunteers recruited from an already existing pool of volunteers or the recruitment of new volunteers may be seen as legacies of the event (Dickson, Benson, Blackman \& Terwiel, 2013; Doherty, 2009; Koutrou, Pappous \& Johnson, 2016; Sand, Strittmatter \& Hanstad, 2017). Hence, apart from the expectations volunteers may have, the volunteer experience is important for retention, as there is a critical link between volunteer motivation and experience. The volunteers need to be trained and feel committed to the event and doing a good job. Moreover, they may also create legacies, motivating them to volunteer in the context of other major sport events (Doherty, 2009).

The purpose of this article is twofold: Firstly, we shed light on the expectations, experiences and legacies as perceived by volunteers at two events of the same type (Nordic WSC), but staged in two different places and two different cultural settings. Secondly, we also investigate the contextual differences between the events in order to elaborate the communalities and differences of these two events and to present implications of our findings.

\section{Literature review and theoretical framework}

Elite and sport for all events alike depend on the hard work of volunteers, who often are the largest stakeholder group within an event (Parent \& Smith-Swan, 2012). As a result, research on volunteers and volunteering has become more popular in recent decades, with a growing range of scholarly journals discussing volunteer topics (Wilson, 2012). The approaches to volunteer research are very often discussed across several disciplines (Hustinx, Cnaan \& Handy, 2010).

Volunteers are a rather complex group of people and there are several types of volunteers: short- or long-term volunteers, who simply contribute to the organization, sponsor-paid volunteers or secondees as well as indirect volunteers, who volunteer for their clubs (Skirstad \& Kristiansen, 2017). Accordingly, the different groups will arrive with different motives for the job and have different experiences before, during and after a sport event. Regardless of the type of the event, it is vital for the organizers to possess this knowledge in order to understand why some people volunteer and others do not, and similarly, why some people who volunteer will continue to do so while others will find volunteering less rewarding and may not volunteer again.

Volunteering motivation has been the object of numerous studies in the literature on sport and event management in general (e.g. Allen \& Shaw, 2009; Burgham \& Downward, 2005; Cuskelly, Taylor, Hoye \& Darcy, 2006; Doherty, 2009; Downward, Lumsdon \& Ralston, 2005; Downward \& Ralston, 2006; Farrell, Johnston \& Twynam, 1998; Love, Hardin, Koo \& Morse, 2011; MacLean \& Hamm, 2007; Pauline \& Pauline, 2009; Ralston, Downward \& Lumsdon, 2004; Schlesinger \& Gubler, 2016; Werkmann, 2011; Wollebæk, Skirstad \& Hanstad, 2014;). Furthermore, Farrell, Johnston and Twynam (1998) developed a 28-item scale known as the Special Event Volunteer Motivation Scale (SEVMS). Accordingly, these researchers defined the following groups of motives: purposive motives, solidary motives, external traditions and commitments. A lot of this research is concerned with the two volunteer trends (collective and reflexive), pointed out by Hustinx and Lammertyn (2003). Based on the modernization theories of Beck (1992) and Giddens (1991), the two researchers sought to understand late modern volunteerism by making a distinction between collective and reflexive volunteerism. Hustinx and Lammertyn claim that volunteerism is influenced by the dissolution of traditional and rigid social configurations, including the core family, traditional sex roles, class and religion. Aspects such as duty, habit, responsibility and tradition are prominent in collective volunteerism. In contrast, the individual's desires are much more dominant in reflexive volunteerism. The collective volunteers have intrinsic motives (Hustinx \& Lammertyn, 2003). 
Furthermore, a typical trait of reflexive volunteerism is that the participant has weak ties to the organization. A decoupling of membership and volunteering takes place (Putnam, 2000). One characteristic is that volunteering is limited in time and space and increasingly event-based. It is the event (e.g. World Championships) and not the organization hosting the event that is central for the reflexive volunteer. Accordingly, young people with high education will be found in this group of volunteers (Kristiansen, Skille \& Hanstad, 2014). However, the analytical framework should be seen as a flexible continuum between the two extremes. This is important, as sport event organizers cannot work solely with reflexive volunteers, as they might need the commitment and experience/knowledge of the specific type of sport that the traditional volunteers possess. A typical theoretical approach has investigated new trends by quantitatively showing a trend in volunteering, which goes away from traditional volunteerism and towards a more individualized form of volunteerism (Hustinx \& Lammertyn, 2004; Wollebæk et al., 2014).

To summarize the literature review, we can say that in regards of volunteer motivation the literature is rich. Also the topic of volunteer satisfaction (and therefore of volunteer experience) is quite well covered by scholars (e.g. Ralston et al., 2004) as well as the expectations of volunteers as described by Werkmann (2011). Regarding volunteer legacies on occasion of sport events, interesting insights are given by Doherty (2009) or Love and coworkers (2011). At this point, it also must be noted, as already observed by Kristiansen, Skirstad, Parent and Waddington (2015), that volunteering has been examined mainly from an individual perspective and not from a community level perspective. This may also become an important part of our study. Hence, to our best knowledge, an analysis and combination of all three aspects and a comparison of the same event in different cultural settings do not exist.

Omoto and Snyder (1995) developed a conceptual model for volunteers, as each volunteer runs through a typical process, comprising the following stages: antecedents, experiences and consequences. This Volunteer Process Model (VPM) explains on different levels (individual, interpersonal, organizational and cultural) what the volunteer learns and does and, therefore, what is required from the organization when offering the volunteer work. For this research project the model of Omoto and Snyder (1995) has been combined with two other models: firstly, with the model developed by Peters and Schnitzer (2015) in the context of analyzing the expectations, experiences and legacies of athletes of major sport events and, secondly, with the concept of the legacy cube for major sport events introduced by Preuss (2007). By analyzing how a single stakeholder percepts an event, Peters and Schnitzer (2015) state that the experience of an event depends on the expectations of the stakeholder, but also on other influencing factors such as the personal setting or the environment. The perceived experience of an event might cause further actions, attitudes or behavior and can be seen as a legacy of the event. Legacies, as described by Preuss $(2007,211)$ in his legacy cube, are "all the planned and unplanned, positive and negative, intangible and tangible structures created by and in connection with a sports event that remain for a longer period than the event itself".

Considering the mentioned theories and the requirements of this study, we propose a theoretical framework suited for analyzing and comparing the volunteers of the two FIS Nordic World Ski Championships based on the phases a volunteer runs through when working for an organizing committee. This volunteer journey can be split into the three phases "expecta-

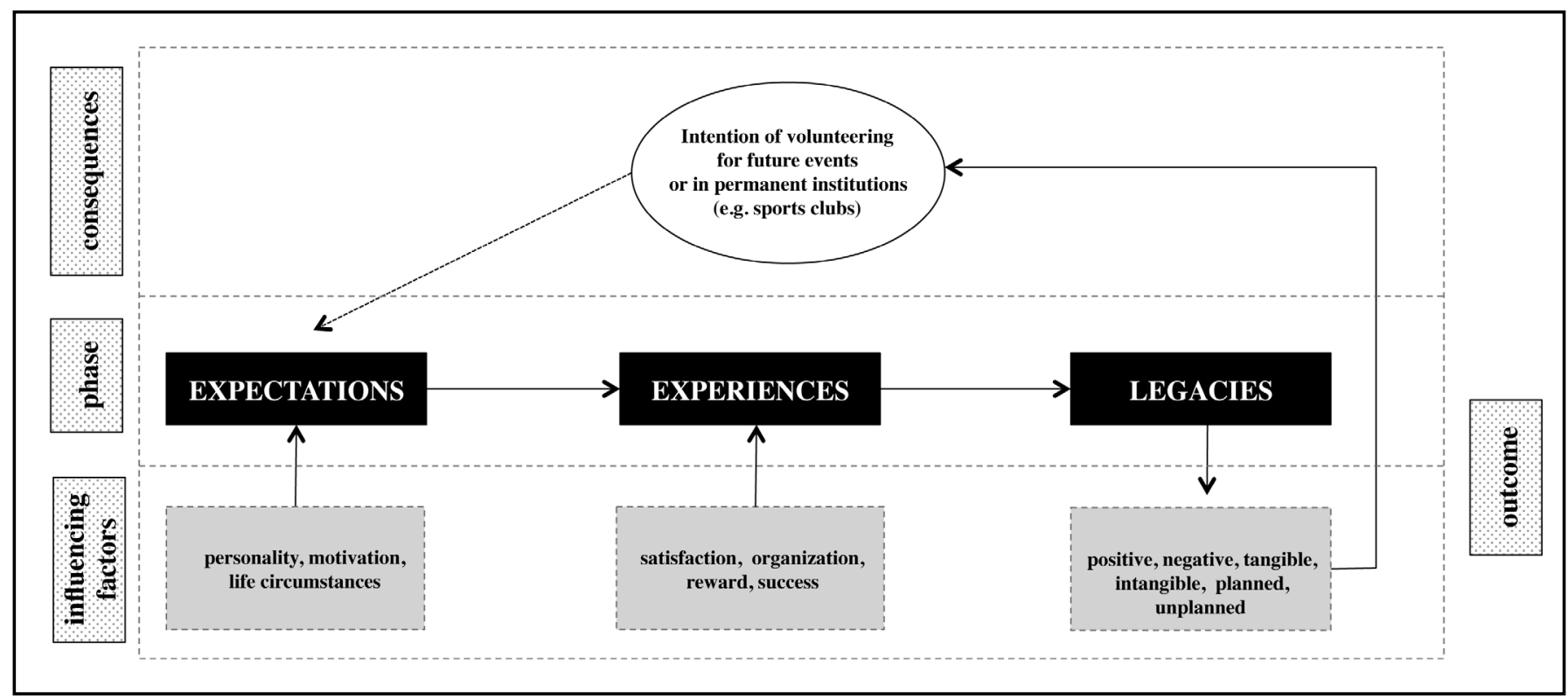

Figure 1: The volunteer journey in a major sport event and its influencing factors for the expectation and experience as well as the legacies as a consequence of the expectations and experiences. 
tions", "experiences" and "legacies", which may be influenced by different aspects. Within the expectations phase, the motivation driving people to volunteer at an event and understanding their personality or life circumstances are important factors. Regarding the experiences, it is important to understand what is needed to satisfy volunteers, how well the organizing committee performs and what kind of rewards (if any) create a good volunteers experience. By bringing together the expectations (prior to the event) and the perceived experiences (mainly) during the event, the volunteer experience might create legacies (e.g. volunteer uniforms, which may have a long lasting value and utilization). The legacies may be the driving force for future volunteer activities (e.g. at other events or in permanent institutions like sport clubs).

\section{Contextual background to the study - the FIS Nordic World Ski Championships Oslo 2011 and Val di Fiemme 2013}

The FIS Nordic WSC in Oslo (Norway) took place from February 23 to March 6, 2011 at the national venue Holmenkollen for the fifth time. This venue also hosted the Nordic WSC in 1930, 1966 and 1982 - while the Olympic Games took place there in 1952. A total of 580 athletes from 49 nations participated; 275,000 tickets were sold and it was estimated that 300,000 spectators were present outside the arena and along the outer tracks during the Championships. The medal ceremonies were held in the city center of Oslo with approximately 50,000 spectators in attendance. After the men's cross-country relay, the police estimated the number of spectators at 100,000 people. Approximately 35,000 campers were observed in the nearby woods and along the courses. For the hosting of this event 2,300 volunteers were recruited through an electronic application process via a proprietary online staff portal. The web portal for the volunteers was used for recruitment, communication, training, different registrations/sign-ups and staff plans. The Nordic WSC organizing committee focused on diversity and wanted to recruit young people and people from different cultural backgrounds.

The FIS Nordic WSC in Val di Fiemme (Italy) took place from February 20 to March 3, 2013. Athletes from 57 nations competed in 21 medal events; a total number of 400,000 spectators followed the competitions (FIS World Championships Fiemme
2013, 2013). After 1991 and 2003, 2013 was the third time that the Italian winter ski resort Val di Fiemme (Fiemme) hosted the Nordic WSC. The region of Trentino in general, but Fiemme in particular, has a long tradition of hosting international sport events. More than 120 FIS World Cup races (cross-country skiing, ski jumping, Nordic combined) have taken place there in the last 20 years and, by hosting the Nordic WSC for the third time in 22 years $(1991,2003,2013)$, the location set a new world record. During the 12 days of the Nordic WSC around 1,400 volunteers helped to make the event a success, among them more than 300 students from the region. All in all, the team consisted of a good mix of young and elderly volunteers. All of them participated in extensive volunteer preparation, consisting of specific training courses (e.g. team building, table-tops), English lessons and volunteer test events during the 2012 Pre-World Championship races (Organizing Committee Trentino Fiemme 2013, 2013b).

\section{Method}

The data for this case study was gathered during two versions of the FIS Nordic World Ski Championships. We selected the two editions of the Nordic WSC due to the time frame, as they were the closed possible editions (2011 and 2013) being staged in a North and South European context and having different settings, but not having too big cultural difference (e.g. like it would be when comparing a European with an Asian country). For the purpose of the study a qualitative research approach, namely the method of guided interviews, was chosen. Data was collected from volunteers during the Nordic WSC. Based on the two examples (Oslo 2011, Val di Fiemme 2013), we interviewed 29 volunteers by conducting a convenient and purposeful sampling procedure since we wanted different levels of responsibility to be represented (Strauss \& Corbin, 1998). Table 1 provides an overview of the participants interviewed in the two samples of volunteers (table 1).

Based on the theoretical frame, the interview guidelines focused on the expectations, the actual experiences and the expected and/or experienced legacies. Furthermore, the interviewed volunteers were asked about their background (e.g. personal information, experience as volunteers, volunteering as a family tradition), the specific role/job at the Nordic WSC, including the length of assignment, the motivation to volunteer

Table 1: Overview of the 29 interviewed volunteers from two events

\begin{tabular}{lll}
\hline Event & Gender and position & Responsibilities \\
\hline $\begin{array}{l}\text { NWSC Oslo; } \\
\begin{array}{l}\text { Norway } \\
\text { 2011, n=14 }\end{array}\end{array}$ & $\begin{array}{l}\text { 3 Head Volunteers (2 female and 1 } 11 \text { regular volunteers (8 female } \\
\text { and 3 male). Age range: 20-67 }\end{array}$ & $\begin{array}{l}\text { Sport initiations, Media communications, Sport and Production services, } \\
\text { Hospitality, Medal ceremony, Result services, Technical support }\end{array}$ \\
$\begin{array}{l}\text { NWSC Val di } \\
\text { Fiemme, Italy }\end{array}$ & $\begin{array}{l}\text { 5 Head Volunteers (1 female, 4 male), } \\
\text { male). Age range: 18-78 }\end{array}$ & $\begin{array}{l}\text { Registration, Accreditation, General secretary, Assistant for disabled per- } \\
\text { sons, Medical services, Media service center, Technical support, VIP hos- } \\
\text { pitality, Results services, Information, Medal ceremony, Venue support, } \\
\text { Parking }\end{array}$ \\
\hline
\end{tabular}


at the event, benefits of being a volunteer, perception of training programs, identity/community and satisfaction; at the end of each interview the volunteers were asked the open process feedback question: "Do you have anything else to add?".

It was important that the sample represented both genders, different age groups, different venues (e.g. Cavalese, Predazzo, Lago di Tesero) and a mix of volunteer roles. We tailored an interview guide and some adjustments were made for the different interviewees due to the site. The human resources department of the organizing committee gave recommendations for potential participants, with whom the researchers then arranged appointments for the interviews. All interviews were developed and conducted according to the ethical guidelines and criteria stated by Patton (2012). Due to the fact that no international volunteers participated, all interviews were conducted in Norwegian/Italian and lasted between 20 and 50 minutes. The interviews were translated into English to enable the research team to do their comparative analyses. Themes, quotes and paraphrased quotes representing a meaningful point or thought were identified individually. We read and coded the raw material and assigned it to main categories and then to sub-categories. The emerging findings were once more compared with the data to verify the understanding and were discussed with colleagues.

\section{Results and Discussion}

Based on the concept "expectations, experiences and legacies", the interviews revealed interesting results, which are outlined in the three themes and provided in table 2 . In the discussion we will discuss and analyze the volunteers' view on the expectations, experiences and legacies of the two events they were involved in. In addition to the table, quotes were included in the presentation and interpretation of the data.

\section{Expectations}

In the case of Norway, $25 \%$ of the volunteers were members of a ski club, which is surprising in Norway. This is also exemplified by a theme that was found only in the Norwegian sample - namely that the interviewees are engaged in volunteering because of their interest in ski sport. In addition, the Norwegian sample of volunteers displayed a more individualistic orientation - in contrast to the collective orientation of volunteerism (Hustinx \& Lammertyn, 2003). This distinction of the motives for volunteering suggests that the first orientation refers to a type of volunteer that is changing in line with late modern individualization processes and that sport event volunteers are not determined by social position or static motives when volunteering. For example:

"I saw an ad in the newspaper. Originally, I wanted to volunteer at the Norway Cup this summer [the world's biggest tournament for young football players], but I applied too late.
So then, I thought it would be a good idea to volunteer here" (Oslo, male volunteer, 67).

The interviews further underlined that people volunteer for many different reasons. Several emphasized that they wanted to see the "inside of an event" and what really happens behind the scenes, as one volunteer elaborated: "I wanted to have a position in an important place in this event and I am close to the athletes, which is great - I learn a lot from observing them" (Oslo, male volunteer, 40). Another male volunteer shared his interest in the elite athletes and their job: "I was not aware of all the other aspects of the life of an elite athlete - it is more than the race - it is also the warm up, the media and everything before the medal ceremony" (Oslo, male athlete, 62). However, learning from the athletes was not the only source of learning mentioned in the interviews: "I like to build things from scratch such as being part of hosting an event... and I like to be in the background - so this job is perfect for me" (Oslo, female volunteer, 20).

A more collective approach to volunteerism was found in the Italian sample, when volunteers reported that they volunteer for the local community. Being able "to give something back" was closely linked to the local community in Fiemme: "I live here. It's a very important event for our valley and I felt it was right to make my small contribution, to help in the organization of such an important event for us" (Fiemme, female volunteer, 22). This is also shown when volunteers help each other, as described in the interviews:

"At the finishing post, there are two women responsible for giving the athletes tea (this is their job). One day it snowed and one of them said to me: 'If you get me a shovel, I'll give you a hand clearing the snow!" (Fiemme, male volunteer, 60).

In both cases we can note that the concept of volunteering was not new to these volunteers, as others in the family already volunteered, too: "Yes, my father has been a volunteer for many years and everyone at home does a little volunteering inside and outside the community" (Fiemme, female volunteer, 24). While we find some communality in the personal setting of the volunteers in both groups (e.g. tradition of volunteering for events), we can note that the purposeful motives such as doing something useful and contributing to the society (Farrell et al., 1998) seem to be more important to the volunteers in Val di Fiemme. Maybe this is also because the results of the own team seems less important for Italian volunteers than for Norwegian volunteers: "I see this event as something which has an impact on our image in the world, which shows what we can do; the sporting success of our team has less priority" (Fiemme, male volunteer, 51).

\section{Experiences}

Relating to the experiences volunteers collected during the World Championships, the aspects of socializing, rewarding, 
Table 2: Overview of the main reasons for volunteering at two different events

\begin{tabular}{lll}
\hline phase $\quad$ influencing factors / outcomes $\quad$ NSWC 2011 (Oslo) NSWC 2013 (Val di Fiemme) \\
\hline
\end{tabular}

expected benefits for the local community (e.g. „I become a member of a bigger society than just my local club"; "I like to be part of ,building' and organizing an event"; "the people is why I do it" ${ }^{\prime \prime}$, I am not doing this for the local community, it is because I like to meet new people")

role of volunteering in the family (e.g. "my parents were volunteers"; "I guess the value of volunteering is something I learned from my family “; ", both family and friends are volunteers"; "my entire family is into ski sport")

expectation

personality, motivation, life circumstances

motivation (e.g. „you get to know new people - and they are all happy ${ }^{\prime \prime}$, ,everyone here in Kollen is smiling these days"; "they needed people - and as a retired person I have plenty of time "; "I studied at the University in Oslo, now I am back to refresh my language skills", "my job puts me in close contact with the athletes, because I work in the mixed zone"; "I like to be part of the construction of an event, to prepare everything for others so that they succeed “; "I feel that I contribute as I do a lot of tasks others do not mind to do")

socializing: (e.g. "the clothing signalizes the membership of the group - you automatically talk to everyone with the jacket"; "I get the opportunity to meet new people - happy people "; , the event is very including, things happen here at the venue and also downtown with the medal ceremony ${ }^{\prime}$; "when I wear the jacket, peole ask me how my day was"; "there is a chemistry with most of the people, but there are an age gap and cultural differences among the volunteers")

rewards: ("the clothing does not make a big difference, the costs for taking a two week non-paid vacation from work are higher"; ;"the clothing is a proof that you care and have participated in the WC"; "I am a little disappointed by the pre-training before the event, it was not good enough")

organization: (e.g. „employees here do not care much about the experience we gain by being a volunteer"; "I got the opportunity to see the other side of an event "; "there is an advantage with young people who have a new view expected benefits for the local community (e.g. "it is important for our valley...important that the organizing of the event makes a good impression even though we are a small valley"; „people in this valley believe in the event "; "the media attention is important for our identity and pride ${ }^{\prime \prime}$, it helps you to become part of the society")

role of volunteering in the family (e.g. „my grandfather did all the World Championships and the Tour de Ski and the World Cup events which were held here right from the beginning"; "I was more or less pushed into it, but not against my will, quite the opposite, I was very willing, but my family is full of volunteers"; "the oldest volunteer is 88 and a great character")

motivation (e.g. "I'm volunteering for pleasure, for the chance it gives me, for the contact with people and to meet new people, to contribute"; "I want to be useful for this event because of my passion for sport. I have been working in sport for years"; "you know you're doing something for the place you live in $^{\prime \prime} ;$, it is definitely a new, unique experience")

socializing (e.g. "the relationship between volunteers and superiors is wonderful " ;", we are like sisters and brothers, we get on well with eachother"; ${ }^{\prime \prime}$,we are one great team, even if we don't know each other"; "nobody treats anyone badly here, so I think I'll remember it as a great experience")

rewards: (e.g. "the practical aspects (clothing, souvenirs) are encouraging, too"; "Certainly, I'll take home a jacket with ,Fiemme 2013 Volunteer' written on it, which is not a bad thing, it will make us recognizable... you feel important ${ }^{\prime \prime}$ )

organization: (e.g. "The manager is really good. He gets you involved, he knows how to do his job and is socially skilled“; "relations between volunteers and superiors are excellent " ${ }_{\text {, }}$ I appreciate the organization, because it's really wonderful, well planned") 


\begin{tabular}{|c|c|c|}
\hline phase & influencing factors / outcomes & NSWC 2011 (Oslo) \\
\hline experience & $\begin{array}{l}\text { satisfaction, } \\
\text { organization, } \\
\text { reward, success }\end{array}$ & $\begin{array}{l}\text { working together with old, experienced } \\
\text { people in order to get an optimal re- } \\
\text { sult"; ",there are so many little things } \\
\text { that make up a great event, and you } \\
\text { are not really aware of them unless you } \\
\text { work here") } \\
\text { satisfaction: (e.g. "I get a lot of fresh air } \\
\text { and I feel good about myself"; "WC in } \\
\text { Norway is an unique experience - and I } \\
\text { wanted to be part of it") }\end{array}$ \\
\hline
\end{tabular}

education / skills development / career: (e.g. "I learned how to deal with people and approached difficult situations - it is challenging, but it will be useful in future "; ",you get an experience and perspective that you cannot learn in school "; "you get to see how life really is like for the best athletes"; "I hope to meet someone that can help me later in my career"; ",it is a great experience and I will add it to my résumé"; „I will use this experience and try to get a better job in my own country"; ",you learn things here that you can not learn from a book"; ",you show commitment when volunteering, I think that is important when applying for jobs")

tangible effects: (e.g.,the clothing does not make a big difference, the costs for taking a two week non-paid vacation from work are higher ${ }^{\prime \prime \prime} ;$, the clothing is a proof that you care and have participated in the WC')

intangible effects: (e.g. "the exeperience, curiosity "; "I enjoy expanding my horizon"; "what I do here is very different from my everyday life"; "I have been a volunteer for 30 years because it gives me so much")

\section{NSWC 2013 (Val di Fiemme)}

satisfaction: (e.g. "the experiences with the disabled spectators were great"; "I feel like I've been appreciated by everyone during these $\mathrm{WC}^{\prime \prime}$; "without the volunteers, the World Championships wouldn't be possible - this makes us proud")

education / skills development / career: (e.g. "I became more cultured and improved my skills"; "volunteering here is part of my education path and will help me for the future ${ }^{\prime \prime}$, I'll put this experience on my résumé and when I apply for jobs or do interviews", "we've had many opportunities to get to know foreign journalists, to speak many languages, so l'd say that it's an added value on top of what I expected at the beginning ")

tangible effects: (e.g. "of course, the volunteer outfit is great, I can use it in the future "; "As a benefit, we've got the clothing. This year we've had quite an effort because we've given volunteers 7 important items of clothing")

intangible effects: (e.g."it is about giving not receiving, but you get something back which feels good - also in the long run"; "there's this spirit of sharing and getting to know people "; will be a lifelong memory of this experience and I'll guard it carefully")

social cohesion: (e.g. „in a relatively small community like Val di Fiemme, I believe that volunteers are a fundamental part of society - that's something that remains"; "this event certainly helps to bring us together";

„there's a truly genuine, human relationship, almost an intimate one, between the volunteers in that everyone has the same objective and this, at least I think so, everybody will remember"; ",95\% of the volunteers are locals from Val di Fiemme - so we will work together also in the future "; ,"we've noticed that, compared to 2003, in 2013 there have been many more side events - the square was packed and the atmosphere great - we should do that more often") 
organization and volunteer satisfaction were analyzed. Regarding the rewarding, the volunteer uniform was contested, but seen as a nice memory of a great experience. Several interviewees mentioned that they were proud to wear the uniform due to the good work they did as volunteers; this is also linked to the pride felt within the local community. Our findings corroborate the literature (e.g. Farrell et al., 1998), when we report that rewarding (extrinsic incentives) is less important in the context of volunteering. The experience of volunteering can be seen as a good opportunity for socializing and bringing a group of people together: "we are all brothers and sisters; you've met people and had wonderful, happy times" (Fiemme, male volunteer, 60).

Concerning the organization of the event, it is interesting to note that the Fiemme volunteers feel that FIS acknowledges them for the good organization of the events, having "assigned the World Championships three times to the Val di Fiemme in twenty two years" (Fiemme, male volunteer, 60 . And the volunteers take pride in the work they do: "It's very satisfying on a personal level, because other people, even the athletes and their coach, recognize the work you're doing and congratulate you on the excellent job, you're doing" (Fiemme, male volunteer, 25). Some volunteers of the Norwegian group had the feeling that the paid staff of the organizing committee seemed not to take care well enough of understanding the experiences volunteers have and gain during such an event. The Norwegian sample of volunteers comprised a huge proportion of young women with no experience as volunteers. Their roles were within support functions (media, public relations, hospitality) - rather than organizing the actual competitions (Hanstad, Skirstad, Skille \& Sand, 2011). However, some of the Norwegian volunteers also added that Norway and the Norwegian economy do not appreciate this type of experience:

"I do not believe volunteer experience is appreciated as much as it should be in Norway, I have lived in Canada for many years - and I would have included this experience in my résumé, if I was still living there. In other places they see the importance of a social perspective and not being self-centered, I am not sure, if people believe that we do this, because we want to give something back!" (Oslo, female volunteer, 35$)$

The results of the chapter experience reveal that the success of the own team is less important for the Italian volunteers than for the Norwegian volunteers. This might be because the expectations on the sporting success are lower as probably in a country, where everyone expects the home athletes to win every competition: "in principle, I'll be happier, if the Italians win, but if the Norwegians win, l'll feel satisfied and involved in the event all the same" (Fiemme, female volunteer, 24). Finally, another major difference arises in the enthusiasm level the volunteers showed during the interviews and the strong commitment of the Italian volunteers toward their community.
"Mainly, you know you're doing something for the place you live in. And on top of that, it's for personal satisfaction, because you get a lot out of being with people, meeting new people, a new atmosphere, and it gives you a lot on a personal level, too" (Fiemme, male volunteers, 25).

\section{Legacies}

If volunteers perceive their expectations as fulfilled or maybe even exceeded, this leads to a positive effect on satisfaction and a high possibility that they will volunteer again at other events or even on a long-term scale for voluntary based organizations (e.g. sport clubs). However, as volunteers might not develop expectations on every aspect in advance, satisfaction may not only be a result of fulfilling expectations as supported by the following quote:"To tell the truth, I didn't expect much, because I sent my application late" (Fiemme, female volunteer, 24).

This means legacies may be created not only at the expectation-satisfaction level, but also by unexpected situations the volunteer work may provide. In both cases the (unexpected) skills development and the possibility of adding the experience to a résumé or the hope of meeting contacts that may trigger a future career are important. Due to this fact, volunteering was also made obligatory for students in various fields of education: "I believe that our efforts have been appreciated, also because this year, too, werve managed to get the nursing schools involved, so the students participate and get experience in the field of sports. It is recognized as a lesson for them" (Fiemme, male volunteer, 51). 300 of the 1,400 volunteers were students. These students were also part of one of the event's other major goals:

"We managed to involve the schools and this is important, because it is a training process and we have had excellent results with the students... [This has helped us to reduce the average age]...from 56 to $46 .$. It is the new generation [of volunteers]. Another interesting thing is that $26 \%$ are women. So we've increased the proportion of women" (Fiemme, Head volunteer, male 45).

In both cases volunteering for the events creates intangible effects such as "expanding one's personal horizon" or "it will be a lifelong memory". While most of the intangible effects were expressed on a personal level, territorial (intangible) legacies (Parent \& Smith-Swan, 2012) seem to apply more to the edition of the World Championships in Italy. The interviews reveal that the event creates social cohesion, that the event organizers have paid a lot of attention to doing side events and that activities targeted the local community more. This practical implications go alongside with the findings of Doherty (2009), saying that individuals volunteering for an event need to have the feeling of having given a contribution to their community and having a positive life experience by doing something different. We noticed that expanding one's horizon, as suggested by Doherty (2009), was important for Norwegian volunteers, 
too, while the experience and the community attachment were much stronger in Val di Fiemme. The urban environment might be a reason for the more individualistic values in Oslo, whereas Val di Fiemme is a more rural area, where the social connection and identification with the valley seem to be more intensive, like shown in this final quote:

"95\% of the volunteers are locals from the Val di Fiemme and a few are from the Val di Fassa and the Val di Cembra, two neighboring valleys [...] We're lucky that, here in the Val di Fiemme and in Trentino, volunteering has become something of a culture and we've noticed that, compared to 2003, in 2013 there have been many more side events. And so there's more going on. This is appreciated much by the local community" (Fiemme, Head volunteer, male 45).

Before concluding the discussion, it should be mentioned that the Val di Fiemme approach of volunteering - legacies of volunteering are rather a community benefit than an individual one - is in line with the findings of Kristiansen et al. (2015), where a group of scholars analyzed the volunteer approach of the FIS Ski Flying World Cup in Vikersund (Norway). It shows that in small community volunteering is strongly linked to the benefits an event may bring to the community and to social cohesion. This underlines that the differences between Oslo and Val di Fiemme concerning the expectations, experiences and legacies of volunteering are more likely to be determined by the fact of whether the event is held in a small community (rural) or in a bigger community (urban) than by the difference between volunteering in a Scandinavian or "Italian Alps" context. In order to come back to the research questions, the results and discussion revealed communalities as well as differences between the two groups of volunteers at the Nordic WSC Oslo 2011 and the Fiemme 2013 FIS events. The most important results are summarized in table 3 .

This study is another important step to understanding the expectations, experiences and legacies of volunteers in the context of major sport events.

\section{Limitations}

We recognize that there are some methodological limitations, as we selected two cases, which do not only have cultural differences (Norway vs Italy), but also differences in the geograph-

Table 3: Overview of the most relevant communalities and differences of the volunteers' expectations, experiences and legacies

\begin{tabular}{|c|c|c|c|}
\hline phase & influencing factors / outcomes & communalities & differences \\
\hline expectation & $\begin{array}{l}\text { personality, motivation, } \\
\text { life circumstances }\end{array}$ & $\begin{array}{l}\text { - volunteering for events and volun- } \\
\text { teering in general as something } \\
\text { important in the families of the } \\
\text { volunteers } \\
\text { - purposive motives as key driver for } \\
\text { volunteering }\end{array}$ & $\begin{array}{l}\text { - Val di Fiemme volunteers have a } \\
\text { high expectation that the event is } \\
\text { something good for the commu- } \\
\text { nity and the development of the } \\
\text { region } \\
\text { - Host cities with a different setting } \\
\text { (Oslo => urban, Val di Fiemme => } \\
\text { rural) }\end{array}$ \\
\hline
\end{tabular}

- socializing is important to volunteers at both events

- rewarding (e.g. volunteer uniform) is less important [more in Oslo than in Val di Fiemme]
- high level of esteem and support for the Val di Fiemme volunteers provided by the organizers, while Norwegian volunteers gave also negative feedback towards the organization

- the performance of the own team is more important to Norwegian volunteers than to Italian volunteers

- while the Val di Fiemme volunteers were enthusiastic about the WC, the Oslo volunteers seemed to be more cut-and-dried

- the aspect of social cohesion, the importance of volunteering, bringing all locals together and sharing this experience - for the development of the valley it is a key driver for the Val di Fiemme and the key difference! postive, negative, tangible, intangible, planned, unplanned
- the WC are seen as an opportunity for skills and development as well as something good for the future career

- intangible effects (experience, spirit of sharing) is more important than tangible effects 
ical setting (urban vs rural setting). This makes it difficult to transfer the outcomes to other regions. Another limitation may arise from the fact that we questioned the volunteers about the legacies of the World Championships already during the event. Interviews about legacies should definitely be concluded after the event. The strengths of the present study are that we interviewed volunteers of the same type of event in a different setting and that we asked them about many aspects of volunteering, which hardly can be found anywhere else.

The framework we used (figure 1) was a helpful guide for developing the interviews and structuring the paper; however, there might be the risk that, when using the frame "expectations, experiences and legacies", other approaches concerning the experiences volunteers gain are not respected. Therefore, an idea could be to use tracking systems like they are used in customer journey studies.

\section{Conclusion}

The purpose of this article was to highlight the communalities and differences concerning the expectations, experiences and legacies of volunteers at two events set in different cultural contexts. Both events, in Norway and Italy, try to develop a new generation of volunteers. Given the discussion, it would seem that the retention rate may be higher in Val di Fiemme. This is, of course, also due to the fact that the Nordic WSC were a project-based undertaking, which is therefore limited in time and space. These are typical characteristics of events that attract reflexive volunteers. Furthermore it appears that due to the popularity of the sports and the location of the event in Norway and Italy, the two events attracted different types of volunteers (Hustinx \& Lammertyn, 2003). The findings may have several implications for event managers and the management of volunteers. As shown in figure 1, the volunteer journey can be seen as cycle, whereas the expectations and experiences of volunteers as well as the created legacies may lead to an interest in volunteering at future events again. This means, if expectations are not fulfilled and the volunteers are not satisfied, event managers will hardly find volunteers for future events. Therefore, the right communication, giving the volunteers the opportunity to learn something new, spending a good time in a nice environment and doing something useful for the community are premises that need to be utilized by the event organization. Especially for rural areas where events take place ensuring positive legacies is crucial, as the number of potential volunteers is limited and aspects as social cohesion play an important role. Hence, it appears as though volunteer retention could be increased when it is embedded in something that matters to the people in the host region - such as the love of the valley or the interest in skiing.

Further research needs to be conducted on the specifics of the single events, as the expectations and experiences of the same event (in this case the Nordic WSC) may differ from region to region. This would also help to improve the SEVMS (Farrell et al., 1998) for future events by taking the local and cultural differences of event destinations into account.

\section{Funding}

The authors have no funding or support to report.

\section{Competing Interests}

The authors have declared that no competing interests exist.

\section{Data Availability Statement}

All relevant data are within the paper.

\section{References}

Allen, J. \& Shaw, S. (2009). Women coaches' perceptions of their sport organizations' social environment: Supporting coaches' psychological needs? Sport Psychologist, 23 (3), 346-366.

Bang, H., Won, D. \& Kim, Y. (2010). Motivations, commitment, and intentions to continue volunteering for sport events. Event Management, 13, 69-81.

Beck, U. (1992). Risk society: towards a new modernity. London: Sage.

Burgham, M. \& Downward, P. M. (2005). Why volunteer, time to volunteer? A case study from swimming. Managing Leisure, 10 (2), 1-15.

Cuskelly, G., Taylor, T., Hoye, R. \& Darcy, S. (2006). Volunteer management practices and volunteer retention: $\mathrm{A}$ human resource management approach. Sport Management Review, 9, 141-163.

Dickson, T. J., Benson, A. M., Blackman, D. A. \& Terwiel, A. F. (2013). It's All About the Games! 2010 Vancouver Olympic and Paralympic Winter Games Volunteers. Event Management, 17 (1), 77-92. doi: 10.3727/152599513×13623342048 220.

Doherty, A. (2009). The volunteer legacy of a major sport event. Journal of Policy Research in Tourism, Leisure and Events, 1 (3), 185-207.

Downward, P., Lumsdon, L. \& Ralston, R. (2005). Gender differences in sports event volunteering: insights from Crew 2002 at the XVII Commonwealth Games. Managing Leisure, $10,219-236$

Downward, P. \& Ralston, R. (2006). The Sports Development Potential of Sports Event Volunteering: Insights from the XVII Manchester Commonwealth Games. European Sport Management Quarterly, 6 (4), 333-351.

Farrell, J., Johnston, M. \& Twynam, G. (1998). Volunteer motivation, satisfaction and management at an elite sporting competition. Journal of Sport Management, 12, 288-300. 
FIS World Championships Fiemme 2013 (2013). Fiemme 2013: goodbye World. Press Release. Available at http://site. fiemme2013.com/en/nordiccombined/detail.php?box= news\&uuid $=$ C39220FD80C542808EB662431032A8BA (16.7.2017)

Giddens, A. (1991). Modernity and self-identity: self and society in the late modern age. Stanford: Stanford University Press.

Hanstad, D. V., Skirstad, B., Skille, E. \& Sand, T. S. (2011). "Hjertet og sjelen av mesterskapet" (the heart ans soul of the championship». Rapport om frivillighet under VM på ski $i$ Oslo 2011. Oslo: Norges idrettshøgskole

Hustinx, L., Cnaan, R. A. \& Handy, F. (2010). Navigating theories of volunteering: A hybrid map for a complex phenomenon. Journal for the Theory of Social Behaviour, 40 (4), 410-434.

Hustinx, L. \& Lammertyn, F. (2003). Collective and reflexive styles of volunteering: A sociological modernization perspective. Voluntas, 14 (2), 167-187.

Hustinx, L. \& Lammertyn, F. (2004). The cultural bases of volunteering: Understanding and predicting attitudinal differences between flemish red cross volunteer. Nonprofit and Voluntary Sector Quarterly, 33, 548-584.

IOC International Olympic Committee (2012). Factsheet Youth Olympic Games, up-date July 2012. Available at www.olympic.org/documents. (7.10.2013)

Koutrou, N., Pappous, A. \& Johnson, A. (2016). Post-Event Volunteering Legacy: Did the London 2012 Games Induce a Sustainable Volunteer Engagement? Sustainability, 8, 1221.

Kristiansen, E., Skille, E. Å. \& Hanstad, D. V. (2014). From Community Based Identities to Individual Benefits for Volunteers: A comparison of three sporting events. Scandinavian Sport Studies Forum, 5, 47-68.

Kristiansen, E., Skirstad, B., Partent, M. \& Waddington, I. (2015). We can do it': Community, resistance, social solidarity, and long-term volunteering at a sport event. Sport Management Review, 18 (2), 256-267.

Love, A., Hardin, R., Koo, G. Y. \& Morse, A. (2011). Effects of motives on satisfaction and behavioral intentions of volunteers at a PGA TOUR event. International Journal of Sport Management, 12 (1), 86-101.

MacLean, J. \& Hamm, S. (2007). Motivation, commitment, and intentions of volunteers at a large Canadian sporting event. Journal of the Canadian Association for Leisure Studies, 31, 523-556.

Omoto, A. M. \& Snyder, M. (1995). Sustained Helping Without Obligation: Motivation, Longevity of Service, and Perceived Attitude Change Among AIDS Volunteers. Journal of Personality and Social Psychology, 68 (4), 671-686.

Organizing Committee Trentino Fiemme 2013 (2013). Study Groups - FIS Nordic World Ski Championships Trentino Fiemme2013, Presentation at Study Group meeting, Lago di Tesero, 27.2.2013.

Overbye, M. \& Wagner, U. (2014). Experiences, attitudes and trust: an inquiry into elite athletes' perception of the whereabouts reporting system. International Journal of Sport Policy and Politics, 6 (3), 407-428.
Parent, M. M. \& Smith-Swan, S. (2012). Managing Major Sports Events: Theory and Practice. New York: Routledge.

Patton, M. Q. (2012). Qualitative research and evaluation methods (3rd ed.). Thousand Oaks, CA: Sage.

Pauline, G. \& Pauline, J. S. (2009). Volunteer motivation and demographic influences at a professional tennis event. Team Performance Management: An International Journal, 15 (3/4), 172-184.

Peters, M. \& Schnitzer, M. (2015). Athletes' expectations, experiences and legacies of the Winter Youth Olympic Games Innsbruck 2012. Journal of Convention \& Event Tourism, 6 (2), 116-144.

Preuss, H. (2007). The Conceptualization and Measurement of Mega Sport Tourism. Journal of Sport \& Tourism, 12 (3/4), 207-227.

Putnam, R. D. (2000). Bowling Alone: The Collapse and Revival of American Community, Touchstone, New York.

Ralston, R., Downward, P. \& Lumsdon, L. (2004). The expectations of volunteers prior to the XVII Commonwealth Games, 2002: A qualitative study. Event Management, 9, 13-26.

Sand, T. S., Strittmatter, A-M. \& Hanstad, D. V. (2017). '2016 Winter Youth Olympic Games: planning for a volunteer legacy'. International Journal of Sport Management and Marketing, in press

Schlesinger, T. \& Gubler, R. (2016). Motivational profiles of sporting event volunteers. Sport in Society - Cultures, Commerce, Media, Politics, 19 (10), 1419-1439.

Skirstad, B. \& Kristiansen, E. (2017). Defining indirect volunteers and applying the volunteer cube framework. In A. Benson \& N. Wise, International Sport Volunteering (pp. 122-141). London: Routledge.

Strauss, A. \& Corbin, J. (1998). Basics of qualitative research: Grounded theory procedures and techniques. Thousand Oaks, CA: Sage.

Werkmann, K. (2011). Motivation, Zufriedenheit und Wertschätzung von Sport-Event-Volunteers: Die FIFA Frauen-WM 2011 in Deutschland. Wiesbaden: Springer.

Wilson, J. (2012). Volunteerism Research: A Review Essay. Nonprofit and Voluntary Sector Quarterly, 41 (2), 176-212.

Wollebæk, D., Skirstad, B. \& Hanstad. D. V. (2014). Between two volunteer cultures. Social Composition and motivation among volunteers at the 2010 Test Event for the FIS Nordic World Ski Championship. International Review for the Sociology of Sport, 49 (1), 22-41. 